\title{
Azadirachta indica (Neem) Water Leaf Extract Inhibits Melanin Production and Tyrosinase Activity in B16F10 Melanoma Cells
}

\author{
Thanitsara Songtavisin ${ }^{1, *}$, Benjamart Pratoomthai ${ }^{2}$, Warachin Gangnonngiw ${ }^{3}$, Jarinyaporn Naowaboot ${ }^{4}$
} Thanitsara Songtavisin ${ }^{1, *}$,
Benjamart Pratoomthai $^{2}$,
Warachin Gangnonngiw ${ }^{3}$, Jarinyaporn Naowaboot ${ }^{4}$

'Division of Anatomy, Faculty of Medicine, Thammasat University, Paholyothin Road, Klong Nueng, Klong Luang, Pathumthani 12121, THAILAND.

${ }^{2}$ Department of Basic Medical Science, Faculty of Medicine, Navamindradhiraj University, Thanon Samsen, Dusit District, Bangkok 10300, THAILAND.

${ }^{3}$ Centex Shrimp, Faculty of Science, Mahidol University, Rama VI Road, Ratchathewi, Bangkok 10400, THAILAND.

${ }^{4}$ Division of Pharmacology, Faculty of Medicine, Thammasat University, Klong Nueng, Klong Luang, Pathumthani 12121 THAILAND.

\section{Correspondence}

Thanitsara Songtavisin

Division of Anatomy, Faculty of Medicine Thammasat University, Paholyothin Road, Klong Nueng, Klong Luang, Pathumthani 12121, THAILAND.

Phone no: (66)869840740;

E-mail: wthanits@staff.tu.ac.th

History

- Submission Date: 17-04-2021

- Review completed: 28-05-2021;

- Accepted Date: 07-06-2021.

DOI : 10.5530/pj.2021.13.133

Article Available online

http://www.phcogj.com/v13/i4

Copyright

(C) 2021 Phcogj.Com. This is an openaccess article distributed under the terms of the Creative Commons Attribution 4.0 International license.

\begin{abstract}
Introduction: Abnormal melanin production can cause pigmentary disorder such as hyperpigmentation Finding a potent medicinal plants that can prevent pigment disorder. Objective: This study was to investigate the potential of leaf extract from Azadirachta indica var siamensis valeton to inhibit melanin formation or melanogenesis. Materials and Methods: A.indica leaf extract was tested for phenolic and flavonoid content assay. Tests using 3-(4,5-dimethylthiazol-2-yl)-2,5-diphenyltetrazolium bromide (MTT) assay were administered to determine the toxicity of A.indica leaf extract in B16F10 melanoma cells. Melanin content and tyrosinase activity assays were used to determine the potential for the inhibition of melanogenesis. Data was analyzed using SPSS. Results: It was found that A.indica leaf extract per gram has a total phenolic content of $28.73 \pm 0.30 \mathrm{mg}$ gallic acid equivalents and flavonoid of $12.48 \pm$ $0.00 \mathrm{mg}$ rutin equivalent. In addition, we found that these herbal extracts decreased the melanin content and intracellular tyrosinase activity in B16F10 melanoma cells without any toxicity. This study suggested that the melanin content and intracellular tyrosinase activity in B16F10 melanoma cells were decreased without any cytotoxicity by the A.indica leaf water extract. Conclusion: The findings demonstrated that A.indica leaf water extract inhibits melanin production through reducing tyrosinase activity. These results could be useful as a therapeutic treatment for skin hyperpigmentation disorders as well as an effective ingredient in whitening cosmetics.

Key words: Azadirachta indica, Tyrosinase, Melanin, Melanogenesis, Hyperpigmentation.
\end{abstract}

\section{INTRODUCTION}

Azadirachta indica var siamensis valeton (neem) belongs to the Meliaceae family which has therapeutic implications in disease prevention and treatment. Among phamacological properties of the neem tree includes antioxidant activities ${ }^{1}$. Leaf and bark extracts of $A$. indica have been studied for their antioxidant activities and results of the investigation clearly indicated that they have strong antioxidant potential ${ }^{2-3}$. As our skin is gets older, wrinkles are noticed. This is a result of use and degeneration of the body which is caused by an important component of the skin that loses strength and reduced flexibility which results in lack of moisture and dullness. In addition, there are abnormalities of the skin caused by the formation of too much melanin pigment, which causes the skin to become hyperpigmentation, referred to as melasma, freckles, age spot. While abnormal melanin production can also cause pigmentary disorder as hypopigmentation causes vitiligo, albinism and abnormal hair". Therefore, when the color our skin changes to darker or lighter it is a result of changes in enzymes that stimulate melanin pigment synthesis.

Melanin is a component that causes skin color changes by synthesizing from the melanocyte cells in the epidermis cell layer that is supposed to protect against sunlight that damages the skin. The process of creating melanin is called melanogenesis which is controlled by the most active enzymes in melanin pigment synthesis, including tyrosinase, tyrosinase protein-1 (TRP-1), tyrosinase protein-2 $(\text { TRP- } 2)^{5-6}$. As mentioned above, tyrosinase plays an important role in melanin pigment synthesis. This is possible using the following processes: 1) the breakdown of tyrosine into a substance L-3, 4-dihydroxyphenylalanine (L-DOPA); 2) then transform the L-DOPA into dopaquinone using tyrosinase, which stimulates the synthesis of melanin to 5,6-dihydroxyindole-2-carboxylic acid (DHICA), and TRP-1 that acts against oxidative stress ${ }^{7}$ and changes from DHICA to indole. -5,6-quinone-2carboxylic acid are both enzymes that stimulate the production of melanin.

Previous study showed that microphthalmiaassociated transcription factor (MITF) was an important factor in regulating gene expression in various enzymes that stimulates the production of pigment including tyrosinase enzymes and TRP-1, TRP $-2^{8}$. There are also reports that MITF expression is controlled via 3 mechanisms: cAMP, SCF/cKit (via MAPKs and Or Akt) and the Wnt signaling mechanism, which affects the extracellular signal regulated kinase (ERK) that is a signal transduction protein subsequent melanogenesis ${ }^{9,10,11}$.

There are also reports from in vitro studies of B16 melanoma cells. The extracts found in the neem leaves inhibited the process of melanogenesis using ethanol extraction method ${ }^{12}$ but there is still no clear evidence of what point the inhibition occurs. There are many types of neem leaf substances that have biological and beneficial effects in pharmaceuticals and medicine such as antibacterial, anticancer, antioxidant, and skin ulcer ${ }^{1}$. Neem root extract has also been reported to inhibit melanin pigment production by inhibiting the expression of MITF, TRP-1 and TRP-2 ${ }^{13}$.

Cite this article: Songtavisin T, Pratoomthai B, Gangnonngiw W, Naowaboot J. Azadirachta indica (Neem) Water Leaf Extract Inhibits Melanin Production and Tyrosinase Activity in B16F10 Melanoma Cells. Pharmacogn J. 2021;13(4): 1030-1035. 
There is currently more research being conducted in the area of antiaging medicine as people are more committed to looking after their own health and enjoying the benefits of modern medicine that helps to improve their quality of life which includes the rejuvenation of youth and maintenance of beauty. The focus of society is that antiaging medicine be scientifically accepted and results in good skin health care. However, the demand for using medical equipment and cosmetics that are scientifically accepted results in expensive products in the areas of production and distribution. Presently most cosmetics contain synthetic substances that may affect the health of consumers in the long run. Therefore, there are studies to find ways to reduce the risk of health and increase the use of such cosmetics. By using herbal extracts such as the neem extract as an alternative to synthetics in cosmetics results in less side effects in cosmetics and drugs. Researchers are interested in preliminary studies on the function of skin cells, including melanocyte, by inserting the extract from neem leaves into cells cultured in the laboratory and comparing the results of various chemical reactions in these cells with the control group that did not receive the extract. Information obtained from this research can be used as a basis for further development into human research studies. And the benefits from this study will create knowledge about the effects of extracts to the work of skin cells and will benefit the development of other extracts for use in the pharmaceutical and cosmetic industry in Thailand in the future. This project was aimed to study the effect of $A$. indica (neem) leaf water extract on melanogenesis inhibition. This was done to detect the composition of phenolic, flavonoid and then to test the toxicity of extracts by MTT assay in melanocyte cells. From there it was used to test the properties of neem leaf water extract to inhibit melanin pigment production and tyrosinase in melanocyte cells. The results provide scientific evidence for further study of Azadirachta indica var siamensis valeton in the application of therapeutic treatment for skin hyperpigmentation disorders.

\section{MATERIALS AND METHODS}

\section{Chemicals and reagents}

L-3,4-dihydroxyphenylalanine (L-DOPA), dimethyl sulphoxide (DMSO), synthetic melanin, 3-(4,5-dimethylthiazol-2-yl)-2,5diphenyltetrazolium bromide (MTT), $\alpha$-melanocyte-stimulating hormone ( $\alpha-\mathrm{MSH})$ and kojic acid were from Sigma-Aldrich (USA). Primary antibodies specific for tyrosinase and MITF were from Santa Cruz Biotechnology (USA). Trypsin, penicillin, streptomycin, and fetal bovine serum (FBS) were from Gibco-BRL (USA). All other chemicals were from Sigma-Aldrich, unless otherwise noted.

\section{Azadirachta indica var siamensis valeton leaf extracted}

\section{Plant material}

The A.incida leaves was collected in Burirum Province, Northeast part of Thailand, between January and February 2018. Its botanical identity was determined and authenticated by a taxonomist. A voucher herbarium specimen (SKP 0951303 01) was given by the Faculty of Pharmaceutical Sciences, Prince of Songkla University, Songkla Province, Thailand.

\section{Extraction}

Collected plant material (leaves) was cleaned thoroughly with water, cut into small pieces, boiled in distilled water $(1 \mathrm{~g}$ of plant material in $10 \mathrm{~mL}$ of water) for $1 \mathrm{~h}$ and then filtered. Filtrates were concentrated using a rotary vacuum evaporator and subsequently lyophilized. Water extract yield was $4.0 \%$. The extract was stored in a freezer at $-80{ }^{\circ} \mathrm{C}$ until it was further used.

\section{Determination of Total Flavonoids Content ${ }^{14}$}

The amount of total flavonoids were analyzed using aluminum chloride colorimetric method. Sample $100 \mu \mathrm{L}$ was mixed with $30 \mu \mathrm{L}$ of $10 \%$ aluminum chloride solution. The mixture was allowed to stand at room temperature $(28 \pm 2 \circ \mathrm{C})$ for $10 \mathrm{~min}$ with intermittent shaking. Add 400 $\mu \mathrm{L}$ of DI water then mixed with $30 \mu \mathrm{L}$ of $5 \% \mathrm{NaNO}_{2}$. The absorbance of the mixture was measured at $510 \mathrm{~nm}$ against a blank sample (methanol) without aluminum chloride using a UV-2550 spectrophotometer (Shimadzu, Japan). The total flavonoids content was determined using a standard curve of rutin $(20-100 \mu \mathrm{g} / \mathrm{mL})$. The content was calculated as mean $\pm \mathrm{SD}$ and expressed as milligrams of rutin equivalents (RE) in $1 \mathrm{~g}$ of the extract and dried powder.

\section{Determination of Total Phenolic Compounds Content}

The amount of total phenolics in extracts was determined according to the Folin-Ciocalteu procedure ${ }^{15}$ Samples $(200 \mu \mathrm{L}$, two replicates) were introduced into test tubes; $1.0 \mathrm{~mL}$ of Folin-Ciocalteu's reagent and 0.8 $\mathrm{mL}$ of sodium carbonate (7.5\%) were added. The tubes were mixed and allowed to stand for $30 \mathrm{~min}$. Absorption at $765 \mathrm{~nm}$ was measured UV2550 spectrophotometer (Shimadzu, Japan). The total phenolic content was expressed as gallic acid equivalents (GAE) in milligrams per gram dry material.

\section{Cell culture}

B16F10 mouse melanoma cells were cultured in Dulbecco's modified Eagle's medium (DMEM) (ATCC, USA) with $10 \%$ FBS and $1 \%$ penicillin/ streptomycin $(10,000 \mathrm{U}$ per100 $\mathrm{mg} \mathrm{mL})$, at $37{ }^{\circ} \mathrm{C}$ in an incutated with $5 \% \mathrm{CO}_{2}$. Cells were trypsinized, sub-cultured, and treated with A.indica leaf extract or kojic acids with various concentrations of tested samples for $72 \mathrm{~h}$. Control cells were cultured with complete DMEM media without A.indica leaf extract.

\section{Cell viability assay}

Cytotoxicity of A.incida leaf extract on B16F10 melanoma cells was measured by using MTT assay ${ }^{16} \mathrm{~B} 16 \mathrm{~F} 10$ melanoma cells $\left(2.5 \times 10^{3}\right.$ cells/ well) were cultured into a 96 well plate. After $24 \mathrm{~h}$, cells were treated with A.incida leaf extract $(5,10,50$, and $100 \mu \mathrm{g} \mathrm{mL})$ or kojic acid (100 $\mu \mathrm{g} \mathrm{mL}$ ) for $72 \mathrm{~h}$. After treatment, culture medium was removed and MTT solution ( $0.5 \mathrm{mg} \mathrm{mL}$ in PBS) was added and the plate incubated for $3 \mathrm{~h}$ at $37^{\circ} \mathrm{C}$. Separate supernatant out and DMSO was added to dissolve the formazan product. Negative control cells were treated in the same manner without the tested compound. After incubation at $37^{\circ} \mathrm{C}$ for $15 \mathrm{~min}$, optical intensity was measured at $490 \mathrm{~nm}$ using a microplate reader (TECAN, Switzerland).

\section{Measurement of cellular melanin content}

Total melanin content was measured according to Tsuboi et al. ${ }^{17}$ with some modifications. Briefly, B16F10 melanoma cells $\left(2.5 \times 10^{4}\right.$ cells/ well) were seeded into a 6-well plate and incubated for $24 \mathrm{~h}$ before being treated with various concentrations A.indica leaf extract $(5,10$, 50 , and $100 \mathrm{ug} / \mathrm{mL})$ or kojic acid $(100 \mathrm{ug} / \mathrm{mL})$ in the presence of 100 $\mathrm{nM}$ of $\alpha$-MSH for $72 \mathrm{~h}$. After treatment, cell pellets were dissolved in 1 $\mathrm{mL}$ of $1 \mathrm{~N} \mathrm{NaOH}$ at $100{ }^{\circ} \mathrm{C}$ for $30 \mathrm{~min}$. The OD of the supernatant was measured at $405 \mathrm{~nm}$ using a microplate reader (TECAN, Mannedorf, Switzerland) and the melanin content was expressed as a percentage of the control value. Cells not stimulated with $\alpha$-MSH were used as a negative control group.

\section{Effect of $A$.indica leaf extract on tyrosinase activity in B16F10 melanoma cells}

\section{Measurement of mushroom tyrosinase activity}

The effect of A.indica leaf extract on mushroom tyrosinase activity was determined spectrophotometrically as described previously ${ }^{18}$ with a 
slight modification. Briefly, $20 \mu \mathrm{L}$ of mushroom tyrosinase (200 units/ $\mathrm{ml}$ ) and $20 \mu \mathrm{L}$ of the sample were placed into a 96-well microplate, and then $160 \mu \mathrm{L}$ of $5 \mathrm{mM} \mathrm{L}$-DOPA in $0.1 \mathrm{M}$ sodium phosphate buffer (PBS) pH 6.8 was added per well and incubated at $37^{\circ} \mathrm{C}$ for $30 \mathrm{~min}$. Tyrosinase activity was determined using a microplate reader (TECAN, Switzerland) at the absorbance of $475 \mathrm{~nm}$, and results were expressed as a percentage of the control value (without A.indica leaf extract).

\section{Measurement of intracellular tyrosinase activity}

Intracellular tyrosinase activity was determined using the method described previously ${ }^{19}$ with some modifications. Briefly, B16F10 melanoma cells $\left(2.5 \times 10^{4}\right.$ cells/well $)$ were seeded into a six-well plate and incubated for $24 \mathrm{~h}$ before being treated without or with various concentrations of A.indica leaf extract $(5,10,50$, and $100 \mathrm{ug} / \mathrm{mL})$ or kojic acid $(100 \mu \mathrm{g} / \mathrm{mL})$ in the presence of $100 \mathrm{nM}$ of $\alpha-\mathrm{MSH}$ for $72 \mathrm{~h}$. After treatment, cells were washed with cold PBS and lysed with PBS containing $1 \%$ Triton-X and then frozen at $-80{ }^{\circ} \mathrm{C}$ for $30 \mathrm{~min}$. After thawing, the lysates were centrifuged and the protein concentration was determined by using the Bradford method (Bio-Rad Laboratories Inc., Hercules, CA, USA). Then $100 \mu \mathrm{g}$ protein lysates (adjusted to 100 $\mu \mathrm{l}$ with PBS) and $100 \mu \mathrm{L}$ of $5 \mathrm{mM} \mathrm{L}$-DOPA were placed into a 96-well plate. After incubation at $37{ }^{\circ} \mathrm{C}$ for $1 \mathrm{~h}$, the absorbance was measured at $475 \mathrm{~nm}$ using a microplate reader (TECAN, Mannedorf, Switzerland).

\section{Measurements of cell-free tyrosinase activity}

Cell-free tyrosinase activity was determined according to the method described by Kim et al. ${ }^{20}$. with a slight modification. Briefly, cell lysate of a-MSH-induced B16F10 melanoma (without A.indica treatment) was prepared as described above. The lysate containing tyrosinase (50 $\mu \mathrm{L}$ of $100 \mu \mathrm{g}$ crude lysate) was incubated with $50 \mu \mathrm{L}$ of SG $(5,10,50$ and $100 \mu \mathrm{g} / \mathrm{ml})$ or kojic acid $(100 \mu \mathrm{g} / \mathrm{mL})$, and then $100 \mu \mathrm{L}$ of $5 \mathrm{mM}$ L-DOPA was added to microplate wells. After incubation at $37^{\circ} \mathrm{C}$ for $1 \mathrm{~h}$, the absorbance was measured at $475 \mathrm{~nm}$ using a microplate reader (TECAN), and results were expressed as a percentage of the control value.

\section{STATISTICAL ANALYSIS}

All data were carried out triplicate and the results were presented as mean \pm standard error of the mean (SEM). The values were compared using the one-way analysis of variance (ANOVA) followed by Dunnett's post hoc test for multiple comparisons. P values less than 0.05 were considered to be statistically significant by utilizing the SPSS statistical analysis software (SPSS Inc., Chicago, IL, USA)

\section{RESULTS}

\section{Phenolic and flavonoid compound}

Previous studies reported the effects of phenolic compounds and flavonoids found in beans and other cereals to have an important role in inhibiting melanin pigment production. Similarly, in this study, it was found that the amount of these compounds was found to be high in A.indica leaf when compared to the standard values (Table. 1 at the end of the manuscript). Therefore, it is possible that with the right amount of substance Neem leaves can also be effective in inhibiting melanin production.

\section{A.indica leaf extract exhibits no toxicity effect on B16F10 melanoma cells}

$\mathrm{B} 16 \mathrm{~F} 10$ melanoma cells treated with various concentrations of A.indica leaf extract $(5,10,50$ and $100 \mu \mathrm{g} / \mathrm{ml})$ or kojic acid $(100 \mu \mathrm{g} / \mathrm{mL})$ for $72 \mathrm{~h}$ in the absence or presence of $\alpha$-MSH revealed no significant effect on cell viability (Figure 1).

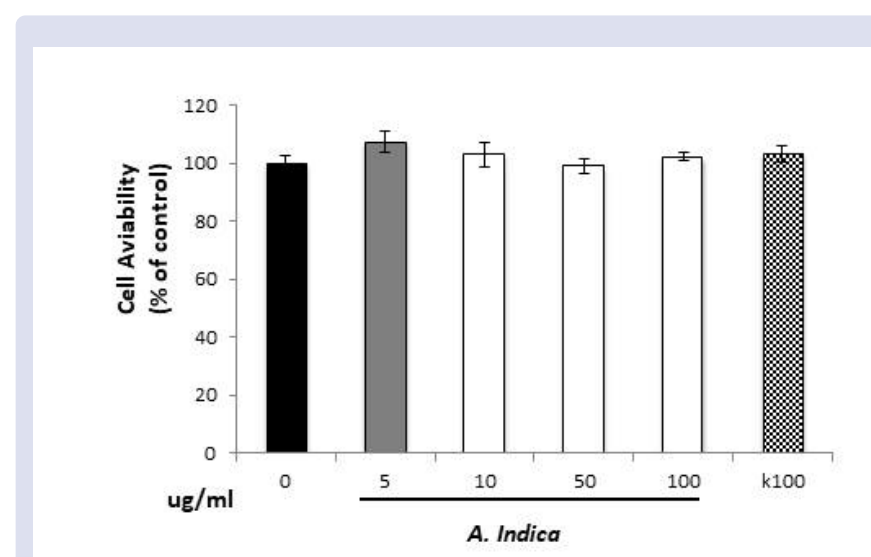

Figure 1: Effect of A.indica leaf extract and kojic acid on cell viability in B16F10 melanoma cells. Baseline cell viability in control wells not exposed to A.indica leaf extract or kojic acid was set at $100 \%$. Data revealed changes correlating with the percentage of control. Each column represents the mean \pm SD of three independent experiments.

Table 1: A.indica leaf extracted has a total flavonoid content of $12.48 \pm$ $0.00 \mathrm{mg}$ rutin equivalent per gram of extract and phenolic acid $28.97 \pm$ $0.27 \mathrm{mg}$ gallic acid equivalent per gram of extract.

\begin{tabular}{ccc}
\hline A.indica leaf extracted & Flavonoid $(\mathrm{mg} / \mathrm{g})$ & Phenolic acid $(\mathrm{mg} / \mathrm{g})$ \\
\cline { 3 - 3 } & $12.48 \pm 0.00$ & $28.97 \pm 0.27$ \\
\hline
\end{tabular}

The toxicity test of A.indica leaf extract was performed by MTT assay by using extracted solvents at different concentrations of $5,10,50,100$ $\mathrm{ug} / \mathrm{mL}$ and using kojic acid which is a commercial whitening agent as a positive control group. Extracts with the highest concentration of $100 \mathrm{ug} / \mathrm{mL}$ had no affect on cell death. Therefore, the A.indica leaf extract, which has a concentration of $\leq 100 \mathrm{ug} / \mathrm{mL}$ can be used for the investigation of an effect of melanogenesis in the B16F10 melanoma cells. The result of this experiment found that A.indica leaf extract at indicated concentrations (up to $100 \mathrm{ug} / \mathrm{mL}$ ) with 72 hours incubation is useful for further studies on melanogenesis. Cytotoxicity showed no significant effects after A.indica leaf extract treatment (Figure 1).

\section{The effects of $A$.indica leaf extract on melanin content in B16F10 cells}

Intracellular melanin content was examined after cells were incubated with A.indica leaf extract. The results from the spontaneous melanogenesis assay showed a significant decrease in melanin levels in cells in a dose-dependent manner (Figure 2a). Cells treated with increasing concentrations of A.indica leaf extract $(5,10,20,50$, and $100 \mu \mathrm{g} \mathrm{mL}$ ) showed levels of melanin content decreasing to 5, 9, 11, 16 and $69 \%$ of control, respectively. Kojic acid decrease the melanin level in cells by $13 \%$ of control $(100 \mu \mathrm{g} \mathrm{mL})$. Moreover, when cells were incubated with A.indica leaf extract in the presence of $\alpha-\mathrm{MSH}$, melanin content was also significantly reduced in a dose-dependent manner, compare to cells incubated with $\alpha$-MSH alone. Melanin content of B16F10 melanoma cells treated with a-MSH become greater to $86 \%$ of control (cells without $a-$ MSH treatment) (Figure 2b).

\section{Effect of A.indica leaf extract on tyrosinase activity in B16F10 melanoma cells}

This study was conducted to observe the effect of A.indica leaf extract and determine whether to directly inhibit it to the tyrosinase enzyme. The experiment was carried out using the mushroom tyrosinase activity method. The results showed that A.indica leaf extracts cannot be directly inhibited (Figure 3a), while kojic acid bleach can be directly 

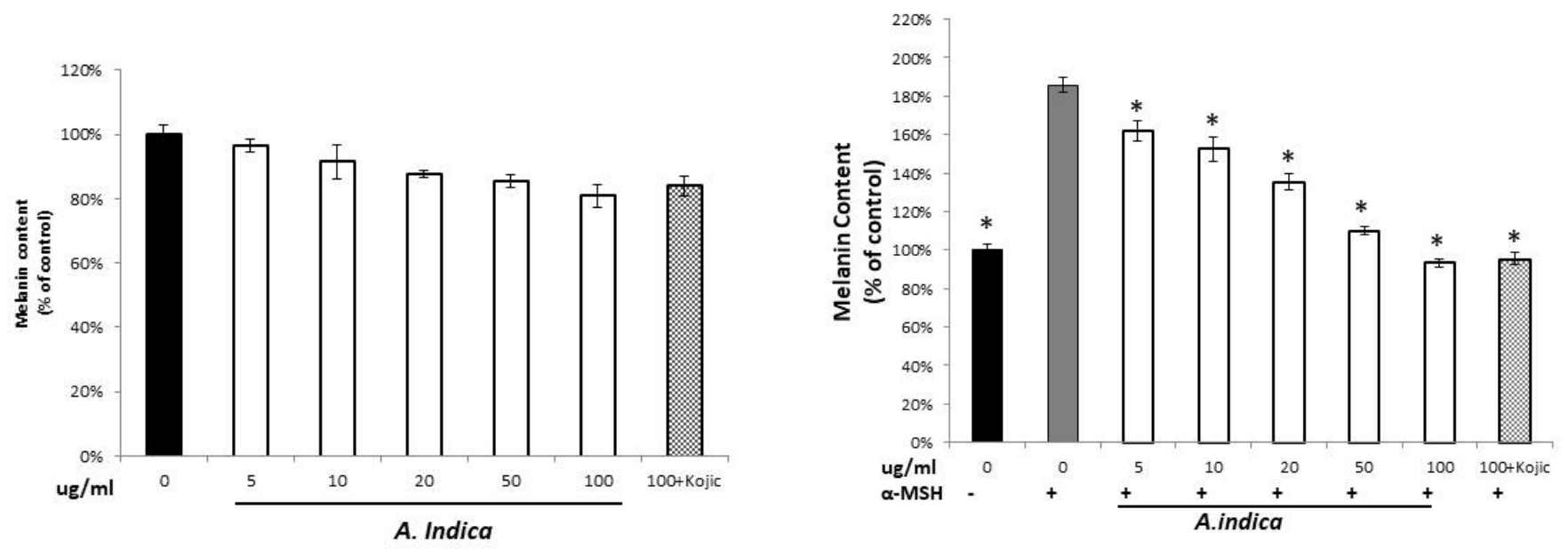

Figure 2: The effect of $A$.indica leaf on melanin in cells B16F10 produced a different level of concentration than cells where $\alpha$-MSH were not administered (a). A comparison study was done with cells receiving $\alpha-\mathrm{MSH} 100 \mathrm{nM}$ (b) within $72 \mathrm{~h}$ to check their melanin content using kojic acid for the positive control group. The baseline melanin content of this group (0) of which kojic acid, $\alpha-\mathrm{MSH}$ or $A$.indica leaf were not administered to was determined. *indicates value significantly different from the $\alpha-\mathrm{MSH}$ treatment group $(\mathrm{P}<0.05)$.
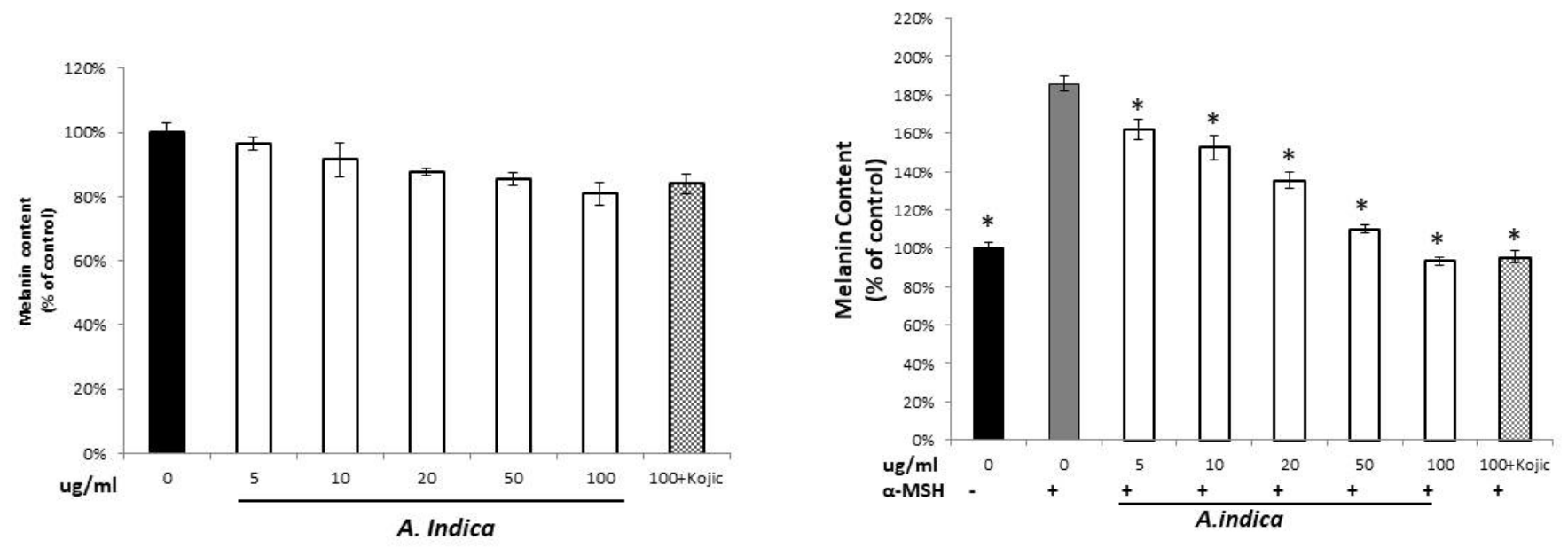

Figure 3: $a$ and $b$ The effects of A.indica leaf extract on direct mushroom tyrosinase activity compared with kojic acid, which is the positive control group (a) and compared with the effect of the extract on the cellular tyrosinase activity when stimulated by adding $\alpha$-MSH (b). The baseline tyrosinase activity in the control group does not include the addition of $A$.indica, kojic acid or $\alpha-\mathrm{MSH}$ ( $100 \%$ of control). Each column represents the mean \pm SD of three independent experiments. \# indicates value significantly different from the $\alpha$-MSH treatment group $(P<0.05)$.

inhibited. From the graph (Figure 3b), the addition of A.indica and a-MSH extracts to test cellular tyrosinase activity can inhibit the process of pigment formation.

\section{DISCUSSION}

The purpose of this study was to investigate the effect of $A$. indica leaf extract on melanogenesis in B16F10 melanoma cell inhibition. In this experiment when studying the toxicity of $A$. indica water extract on cells we found no significant toxicity. As shown in determination of total phenolic compounds content analysis result, A. indica water extract contains a high level of phenolic and flavonoid compounds which have been reported to have multiple biological effects, including antioxidant activity ${ }^{21}$. Flavonoids have potential sources of antioxidant compounds, which are important in the plant for normal growth development and defense against injury ${ }^{22}$. Therefore, it is possible that the properties of the above two components result in protection against cell damage. This results correlate with previous study that reported some compound from the leaves of A.indica were isolated with an $\mathrm{EtOH}$ extract were evaluated for their inhibitory activities against melanogenesis in B16 melanoma cells, induced with a-melanocytestimulating hormone $(\alpha-\mathrm{MSH})^{23}$ exhibited inhibitory activities in reduction of melanin content.

One method to determine the possible mechanism by which $A$. indica leaf extract is to observe its effect on tyrosinase activity which is the enzyme responsible for the synthesis of melanin ${ }^{24}$. The inhibition of tyrosinase activity is the most common target for melanogenesis 
inhibitors. In this study, direct inhibitory effect of $A$. indica leaf extract on tyrosinase activity was observed in mushroom tyrosinase activity assays. The results indicated that $A$. indica water extract has no direct effect on inhibiting mushroom tyrosinase activity. The results indicated that $A$. indica water leaf extract had no direct effect on inhibiting mushroom tyrosinase activity. Nevertheless, this study shows that A. indica water leaf extract could inhibit cellular tyrosinase activity. This would concur with a former investigation revealing the mechanism involved in the melanogenesis inhibitory by some constituent in A. indica hexane leaf extract showed a reduction of protein level expressions which was followed by a decrease in the expression of tyrosinase ${ }^{25}$. Presently, the important compound in $A$. indica water leaf extract to control the cellular function through relevant process such as regulations of the mechanism remains unknown. It is still possible that the $A$. indica water leaf extract could inhibit cellular tyrosinase activity resulting in further inhibition of melanogenesis leading to skin depigmentation. However, further studies on pharmacology is necessary to confirm the results. The results from these experiments indicate that the A.indica leaf extract can inhibit melanin production by reducing the activity of the tyrosinase enzyme, which is the target of the inhibition of melanin production. It was found that A.indica leaf extract is not toxic to cells. Therefore, it is possible to develop A.indica leaf extracts to be used to treat disorders caused by excessive melanin production, such as melasma or other hyperpigmentation symptoms, which may be used as a component in skin whitening cosmetics. This work has thus provided a further evidence of the importance of A. indica leaf extract and its constituents as potential melanogenesis inhibitory agents.

\section{ACKNOWLEDGEMENTS}

The authors gratefully acknowledge the financial support provided by Thammasat University Research Fund under the TU Research Scholar, Contract No.056/2561. We would like to thank Miss Debbie Vik for helping us in correcting our English.

\section{CONFLICTS OF INTEREST}

We declare that we have no conflicts of interest.

\section{REFERENCES}

1. Mohammad A. Alzohairy. Therapeutics Role of Azadirachta indica (Neem) and Their Active Constituents in Diseases Prevention and Treatment. Evidence-Based Complementary and Alternative Medicine. 2016:1-11.

2. P.Sithisarn, R. Supabphol, and W. Gritsanapan, "Antioxidant activity of Siamese neem tree (VP 1209)." Journal of Ethnopharmacology. 2005; 99:1:109-112.

3. A.H.Rahmani and S.M.Aly, Nigella sativa and its active constituents thymoquinone shows pivotal role in the disease prevention and treatment, Asian Journal of Pharmaceutical and Clinical Research. 2015; 8:1:48-53.

4. Naphichaya Phacharapiyangkul, Krit Thirapanmethee, Khanit Sangiamsuntorn, Uraiwan Panich, Che-Hsin Lee, Mullika Traidej Chomnawang. Effect of Sucrier Banana Peel Extracts on Inhibition of Melanogenesis through the ERK Signaling Pathway. Int. J. Med. Sci. 2019; 16:602-606.

5. Del Marmol $V$, Beermann F Tyrosinase and related proteins in mammalian pigmentation FEBS Llett. 1996;381: 165-168.

6. Lee YS Inhibitory effect of glyceollin isolated from soybean against melanogenesis in B16 melanoma cells. BMB Rep. 2010; 43:461-467.

7. An Bras Dermatol, Inês Ferreira dos Santos Videiral, Daniel Filipe Lima Mourall, Sofia Magina. Mechanisms regulating melanogenesis 2013; 88(1):76-83.
8. Saha B, Singh SK, Sarkar C, Bera R, Ratha J, Tobin DJ, Bhadra R. Activation of the Mitf promoter by lipid stimulated activation of p38 stress signaling to CREB. Pigment Cell Res. 2006; 19:595-605.

9. Chang TS Natural melanogenesis inhibitors acting through the downregulation of tyrosinase activity. Materials. 2012; 5:16611685.

10. Chan CF, Huang CC, Lee MY, Lin YS Fermented broth in tyrosinaseand melanogenesis inhibition. Molecules 2014; 19:13122-13135.

11. Kim M, Hyun KH, Kim JH, Im S Sim J, Lee N, Hyun CG Antimelanogenesis activities of Sargassum musicum via MITF downregulation. Oriental J Chem. 2017; 33:1589-1594.

12. Mio Takagi, Yosuke Tachi, Jie Zhang, Takuro Shinozaki, et.,al. Cytotoxic and Melanogenesis-Inhibitory Activities of Limonoids from the Leaves of Azadirachta indica (Neem) CHEMISTRY\&BIODIVERSITY. 2014; 11:451-468.

13. Worapong Kitdamrongtham, Hiroyuki Akazawa, Aranya Manosroi, Jiradej Manosri, Yosuke Tachi, Kenta Ishii. et al., Limonoids and Flavonoids from the Flowers of Azadirachta indica var. siamensis, and their Melanogenesis-Inhibitory and Cytotoxic Activities. 2014; 73-84.

14. Malla MY, Sharma M, Saxena R, Mir MI, Mir AH, Bhat SH Phytochemical screening and spectroscopic determination of total phenolic and flavonoid contents of Eclipta alba Linn. J Nat Prod Plant Resour. 2013; 3:86-91.

15. V. L. Singleton, Joseph A. Rossi. Colorimetry of Total Phenolics with Phosphomolybdic-Phosphotungstic Acid Reagents. Am J Enol Vitic. 1965; 16:144-158.

16. Mosmann T. Rapid colorimetric assay for cellular growth and survival: application to proliferation and cytotoxicity assays. J Immunol Methods. 1983; 65:55-63.

17. Tsuboi T, Kondoh $H$, Hiratsuka J, Mishima $Y$. Enhanced melanogenesis induced by tyrosinase gene-transfer increases boron-uptake and killing effect of boron neutron capture therapy for amelanotic melanoma. Pigment Cell Res. 1998; 11:275-82.

18. Rahman A, Choudhary MI, Thomsen WJ. Bioassay techniques for drug development. Boca ha8 Raton, FL: CRC Press. 2001.

19. Busca R, Bertolotto C, Ortonne JP, Ballotti R Inhibition of the phosphatidylinositol 3-kinase/p70(S6)-kinase pathway induces B16 melanoma cell differention. J Bio Chem. 1996; 271: 31824-31830.

20. Yeon Mi Kim, Jieun Yun, Chong-Kil Lee, Hwanghee Lee. et al., Oxyresveratrol and Hydroxystilbene Compounds INHIBITORY EFFECT ON TYROSINASE AND MECHANISM OF ACTION. Journal of biological chemistry. 2002;277, 16340-16344.

21. Marja P. Kahkonen, Anu I. Hopia, Heikki J. Vuorela, Jussi-Pekka Rauha, Kalevi Pihlaja, Marina Heinonen. et al., Antioxidant activity of plant extracts containing phenolic compounds. J. Agric. Food Chem. 1999; 47: 3954-3962.

22. Richard A. Larson. The antioxidants of higher plants. Phytochemistry. 1988; 27: 969-978.

23. Mio Takagi, Yosuke Tachi, Jie Zhang, Takuro Shinozaki, et.,al. Cytotoxic and Melanogenesis-Inhibitory Activities of Limonoids from the Leaves of Azadirachta indica (Neem). CHEMISTRY\&BIODIVERSITY. 2014; 11:451-468.

24. Gertrude-E Costin, and Vincent J. Hearing. Human skin pigmentation: melanocytes modulate skin color in response to stress. FASEB J. 2007; 21:976.

25. Aranya Manosroi, Worapong Kitdamrongtham, Kenta Ishii, Takuro Shinozaki, Yosuke Tachi. et al., Limonoids from Azadirachta indica var. siamensis Extracts and Their Cytotoxic and MelanogenesisInhibitory Activities. Chemistry \& Biodiversity. 2014; 505-531. 


\section{GRAPHICAL ABSTRACT}

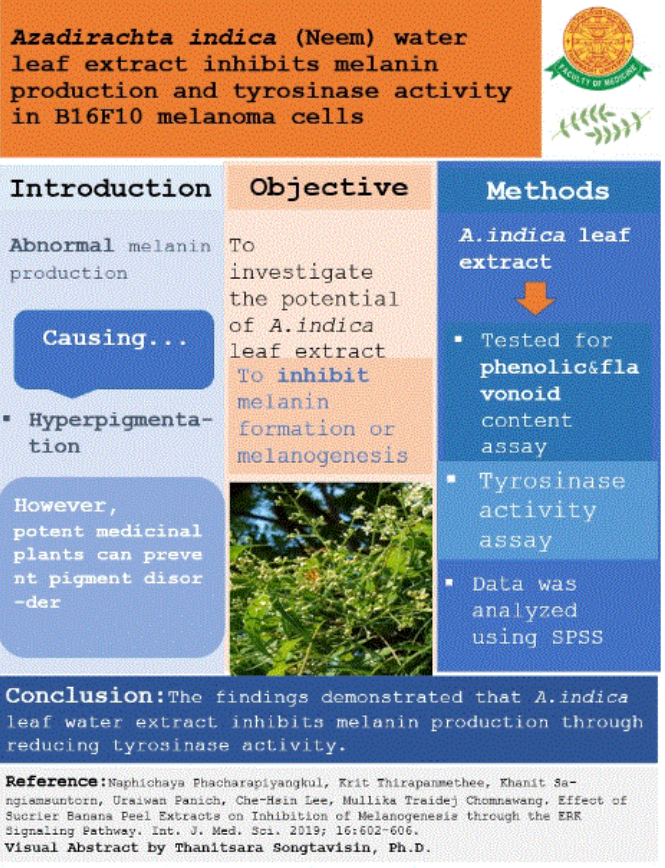

\section{ABOUT AUTHORS}

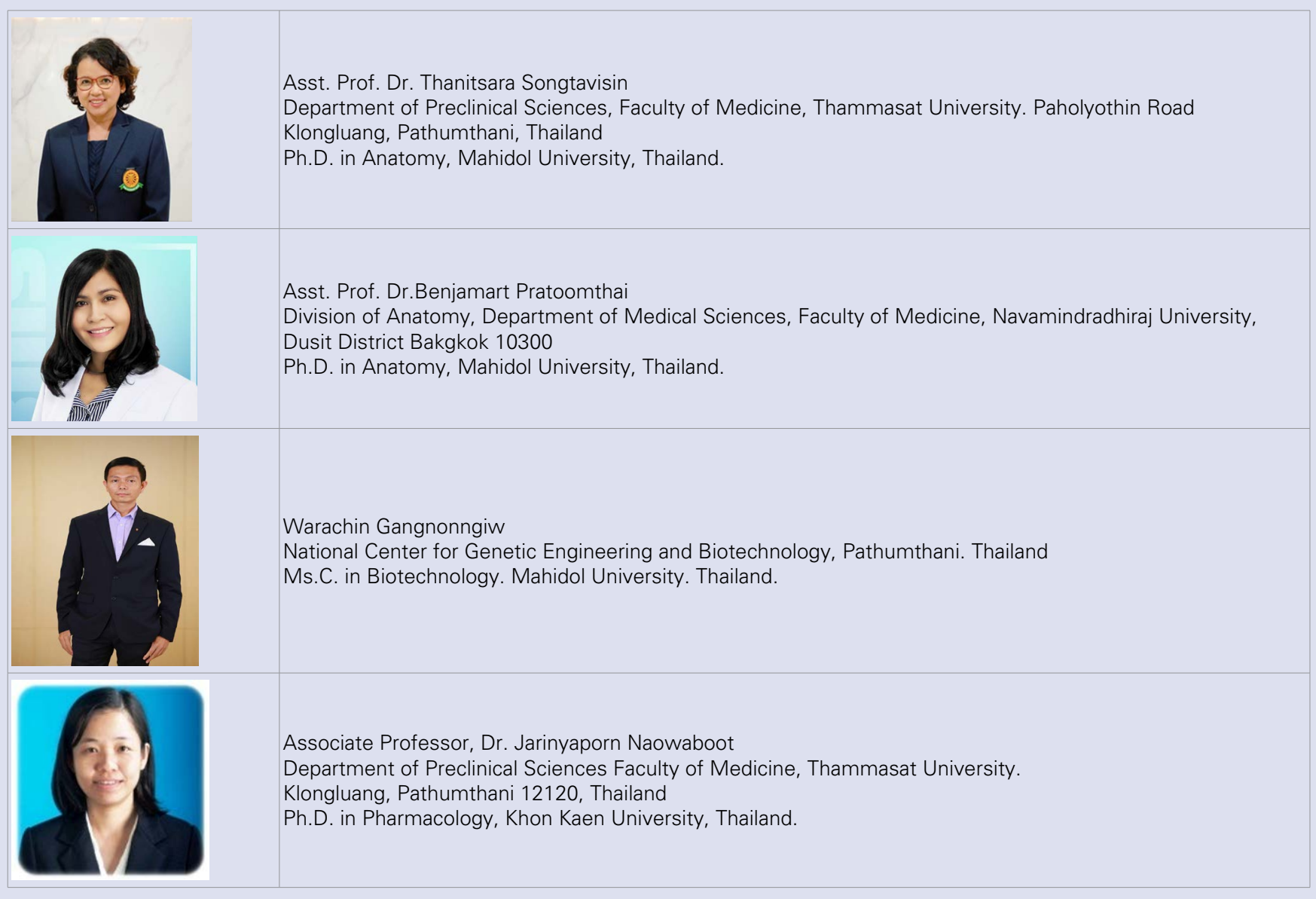

Cite this article: Songtavisin T, Pratoomthai B, Gangnonngiw W, Naowaboot J. Azadirachta indica (Neem) Water Leaf Extract Inhibits Melanin Production and Tyrosinase Activity in B16F10 Melanoma Cells. Pharmacogn J. 2021;13(4): $1030-1035$. 